Asian-Australasian Journal of

Food Safety and Security

ISSN 2523-1073 (Print) 2523-2983 (Online)

www.ebupress.com/journal/aajfss

\title{
Article \\ Impact of society for social service credit on poor women of Mymensingh district in Bangladesh
}

\author{
Md. Ashraful Alam ${ }^{1}$, Syful Islam ${ }^{2 *}$, Nowrin Islam Toma ${ }^{3}$ and Md. Shofiqul Islam ${ }^{4}$ \\ ${ }^{1}$ Department of Agricultural Economics, Bangladesh Agricultural University (BAU), Mymensingh \\ ${ }^{2}$ Agricultural Economics Division, Bangladesh Institute of Nuclear Agriculture (BINA), Mymensingh \\ ${ }^{3}$ Department of Agricultural Economics, Bangladesh Agricultural University (BAU), Mymensingh \\ ${ }^{4}$ Agricultural Economics Division, Bangladesh Sugarcrop Research Institute (BSRI), Ishwardi, Pabna
}

*Corresponding author: Syful Islam, Agricultural Economics Division, Bangladesh Institute of Nuclear Agriculture (BINA), Mymensingh, Bangladesh. E-mail: bausyful07@gmail.com

Received: 20 September 2019/Accepted: 31 October 2019/ Published: 30 November 2019

\begin{abstract}
The present study is an attempt to assess the impact of SSS (Society for Social Service) credit on women beneficiaries of Gouripur upazila at Mymensingh district in Bangladesh. The study revealed that both annual income and expenditure of the respondent households have increased after joining the micro credit program of SSS. Average family size of agriculture and petty business enterprises were 4.69 and 4.21. Average annual income of agriculture and petty business enterprises were Tk 80726.57 and 74864.14 respectively while average annual expenditure of agriculture and petty business enterprises were Tk 78776.65 and 67912.37 respectively. It was evident in the case of children education (60.00 percent), labor employment (40.00 percent), crop production (55.00 percent), taking care of children (30.00 percent) and rearing poultry birds. The highest (66.67 percent) proportion of the respondents reported insufficiency of credit supply was a moderate problem and only 33.33 percent of them reported this not at all a problem to them. The interest rate charged by the SSS as a major problem, 36.67 percent of the respondents opined as high. About 48.49 percent of the respondents reported that burden of old debt was not at all a problem while 1.67 percent said that it was a great problem to continue their existing activities. The finding shows that SSS credit program encouraged the women beneficiaries to participate in the social development activities in the study area.
\end{abstract}

Keywords: impact; beneficiaries; credit; social; women

\section{Introduction}

Bangladesh is one of the most densely populated countries of the world with a population of 159.9 million. Its density of population is 1215 persons per sq. $\mathrm{km}$. which is one of the highest in the world. The current population growth rate is 1.05 percent per annum (BBS, 2016). The incidence of poverty in Bangladesh is alarming. Among the 177 countries of the world, the position of Bangladesh is 142 in terms of Human Development Index (UNDP, 2016). The recent estimate of the head count ratio is 23 percent for Pakistan, 27 percent for Sri Lanka and 35 percent for India. According to most of the usual indices of quality of life and of economic development, women in Bangladesh are disadvantaged in comparison to men. Traditional attitudes and customs in Bangladesh are the major obstacles to improve the situation of women. Women are not only the poorest of the poor; they are also disproportionately represented among the poor. About 70 percent of its total population live in rural areas and are directly or indirectly engaged in wide range of agricultural activities (MoF, 2016). Micro credit could have by now reached over 60 percent of all poor households of the country and 37 percent of all households (SSS, 2016).

Bangladesh is the pioneer of microcredit program in the world. At present more than 10000 micro finance institutions are operating in the country. These NGOs are one of the most important income generating 
mechanisms available to low income people, small entrepreneurs and marginal producers. Micro credit from the NGOs is more popular among the rural poor than any other institutions of Bangladesh (Jalil, 2005). Now, the rural poor in Bangladesh can at least be hopeful for improved future life because of different micro-credit programs adopted by various NGOs. The dependency of the rural poor on unscrupulous moneylenders is gradually declining due to micro credit program initiated by the govt. and various NGOs. This program can ensure poor people to be self-employed (Bulbul, 2010). It increased awareness of the rural poor and also encourages women in different income generating activities (IGAs).

SSS (Society for Social Service) a reputed national NGO has been working in Bangladesh since November, 1986 to help the rural distressed people. To alleviate poverty, it has launched a comprehensive program including self-employment, education for empowerment, income generation, etc. SSS believes that economic empowerment is the vital factor of development along with other factors like social, political and cultural aspects. Therefore, improvement of economic conditions has been considered to be the key factor in solving other problems through increased income. With this end in view, SSS initiated credit services program from the middle of 1991. The mission of SSS is to reduce poverty and to improve rural livelihood through provision of micro finance services in an innovative and sustainable way. With this philosophy, SSS has been specialized in providing credit for income generation of the landless poor where savings mobilization was a part of the credit program. The specific objectives were: i. to assess the socio-economic characteristics of SSS beneficiaries in the study area; ii. to determine the adequacy of SSS credit, its utilization and repayment by the respondents; iii. to investigate into the impact of SSS credit on some socioeconomic aspects of the beneficiaries in the study area; and iv. to identify the constraints faced by the beneficiaries. SSS works with a vision to bring just an enlightened, healthy and democratic Bangladesh free from hunger, poverty, environmental degradation and all forms of exploitation based on age, sex, religion and ethnicity.

\section{Materials and Methods}

\subsection{Selection of the study area}

Farm management research requires selection of an area where the research is to be conducted and related information requires to be collected. Moreover, the area in which farm business survey is to be conducted depends on the specific purpose of the survey and the possible co-operation from the respondents. Keeping this in mind five villages namely Kalipur, Kashier char, Sarker para, Shantibag and Shamvugonj under Gouripur upazila of Mymensingh district were randomly selected for the present study. The main reasons for selecting the villages were: (i) poverty reduction and women development program of SSS were in operation in these areas and SSS officials were more or less known to the researcher; (ii) credit receivers were available in the study area; (iii) the selected area is well served by roads and rickshaw services; and (iv) perfect cooperation with the respondents so that reliable data might be obtained (Alam, 2005).

\subsection{Period of survey}

For the present study, data were collected by the researcher himself through personal interviews with the selected women. The period covered in present study was January to December, 2016. Data were collected during the months of August to September, 2017.

\subsection{Selection of the sample}

In a complete enumeration required information are collected from each and every element of the population making the survey very costly and time consuming. The present study is based on a sample survey of households which could represent reasonably a true picture of the entire population. After selection of the study area, a list of current beneficiaries was collected from the SSS branch office at Gouripur upazila of Mymensingh district. From the list, 90 respondents were randomly selected out of 235 beneficiaries. Their IGAs were mainly confined to agriculture and petty business.

\subsection{Preparation of survey schedule}

In order to prepare final survey schedule for data collection a draft schedule was prepared keeping the objectives in view. The draft schedule was pretested in the study area. In the light of the experience gathered during pretesting necessary correction, modification and adjustment were made in the draft schedule. The final schedule was then cyclostyled and used for collecting data for the study. 


\subsection{Methods of data collection}

Collection of reasonably reliable data from the field is not an easy task. Bodiuzzaman (2006) have suggested three main techniques by which farm survey data can be gathered: (i) direct observation, (ii) interviewing respondents and (iii) reviewing records kept by respondents. Keeping this in mind, direct interview method was followed to collect data from the respondents to whom the researcher would ask questions and recorded the answers very carefully.

\subsection{Processing and analysis of data}

Data were carefully analyzed with a view to achieving the objectives of the study. The collected data were first transferred to master sheets and compiled to facilitate the needed tabulation. The data which were recorded in local units were converted into standard units. Tabular technique was applied for the analysis of data using simple statistical tools like average, percentage, etc.

\subsection{Problems faced in data collection}

During the period of data collection, the researcher had to face some problems, which are as follows:

(i) Most of the respondents initially hesitated to answer the question, as they thought that the investigator might use the information against their interest (Khatun, 2009);

(ii) Due to lower education level, the respondents were initially unable to understand the questions asked by the researcher and in some cases irrelevant answers were given;

(iii) Sometimes it was not possible to collect data though the women were available at home. Because at that time they were busy with their household activities. So it is needed more than one visit to administer a single interview;

(iv) Most of the respondents did not keep proper written records and accounts of -their household activities;

(v) Due to lack of proper knowledge the respondents were indifferent to the objectives of the study and answered the questions in careless manner. However, repeated attempts were made to collect the correct information as far as possible.

In spite of all the difficulties pointed out above it is hoped that the study could fulfill to its objectives by constant persuasion and untiring patience of the researcher that would help for future research and for formulation of policy implications.

\section{Results and Discussion}

\subsection{Socio-economic characteristics of the beneficiaries}

This section has been made to identify the main socio-economic characteristics of the selected beneficiaries in the study area because of the fact that the receipt and utilization of credit might have been influenced by the socio-economic characteristics of the credit receivers. To investigate into the impact of SSS micro credit program, some important as well as relevant socio-economic characteristics of the beneficiaries are taken in to consideration (Asad, 2003).

\subsubsection{Family size and composition}

In this study, a family has been defined as a unit in which a number of people lives together and take meal from the same kitchen under the administration of one head. If any person of a family is employed outside but takes meals from the same kitchen while at home and shares the income and expenditure of the family, she/he has been considered to be a member of that family. Persons who have been employed in a family for household works like servants, day laborers, etc. are excluded in this definition. It is evident in Table 1 that the overall average family size was found to be 4.45 being almost similar to national average of 4.9 (BBS, 2016) which was 4.69 for agriculture group and 4.21 for petty business group. It is apparent from same table that most of the beneficiaries were in the age group of 15 to 57 years i.e. active age group while minimum was found in above 57 years of age during the study period. 
Table 1. Family composition of the respondent households (no.).

\begin{tabular}{llllllll}
\hline & \multicolumn{2}{c}{ Below 15 years } & \multicolumn{2}{c}{$\mathbf{1 5 - 5 7}$ years } & \multicolumn{2}{c}{ Above 57 years } & Average family size \\
\cline { 2 - 7 } Enterprise & Male & Female & Male & Female & Male & Female & \\
\hline Agriculture & 0.69 & 0.74 & 1.56 & 1.66 & 0.04 & - & 4.69 \\
Petty business & 0.65 & 0.66 & 1.36 & 1.40 & 0.06 & 0.08 & 4.21 \\
All & 0.67 & 0.70 & 1.46 & 1.53 & 0.05 & 0.04 & 4.45 \\
\hline
\end{tabular}

Source: Field Survey, 2017

In the case of below 15 years age the male and female members constituted 14.75 and 16.67 percent for agriculture and they were 15.21 and 16.76 percent for petty business enterprise respectively. Similarly when adult respondents are considered, the percentages became 34.10 and 35.48 percent for agriculture, 33.70 and 35.33 percent for the petty business respectively (Table 2). Thus, there was little difference in the sex composition of family members of the respondent households under different categories. The average family size of agriculture group was higher than that of business group during the period of study.

Table 2. Distribution of family members according to gender.

\begin{tabular}{|c|c|c|c|c|c|c|c|c|c|c|}
\hline \multirow[t]{3}{*}{ Enterprise } & \multicolumn{4}{|c|}{ Male } & \multicolumn{4}{|c|}{ Female } & \multicolumn{2}{|c|}{ Total } \\
\hline & \multicolumn{2}{|c|}{ Below 15 years } & \multicolumn{2}{|c|}{ Adult } & \multicolumn{2}{|c|}{ Below 15 years } & \multicolumn{2}{|c|}{ Adult } & \multirow[b]{2}{*}{ No. } & \multirow[b]{2}{*}{ Percent } \\
\hline & No. & Percent & No. & Percent & No. & Percent & No. & Percent & & \\
\hline Agriculture & 32 & 14.75 & 74 & 34.10 & 34 & 16.67 & 77 & 35.48 & 217 & 100 \\
\hline $\begin{array}{l}\text { Petty } \\
\text { business }\end{array}$ & 28 & 15.21 & 62 & 33.70 & 29 & 16.76 & 65 & 35.33 & 184 & 100 \\
\hline All & 60 & 14.96 & 136 & 33.91 & 63 & 16.71 & 142 & 34.42 & 401 & 100 \\
\hline
\end{tabular}

Source: Field Survey, 2017

\subsubsection{Level of literacy}

Education is the key factor for the development of any country. It is now recognized that the problem of illiteracy in Bangladesh is embedded more among females than males. The government and various NGOs have been pursuing different programs to improve literacy rate in the country. National literacy rate ( 7 years and above) of total population is 66.67 percent (MoF, 2016). For the purpose of showing the level of literacy of the participating households, the literacy level was divided into five categories. Table 3 shows that there is no illiterate respondent because of the fact that at least able to sign one's name is a precondition to become member of SSS. The same table shows that persons able to sign their names were 64.44 percent of total in agriculture while it was 37.78 percent in petty business enterprise. The respective percentages of respondents having primary education were 17.78 and 35.55 percent during the study period. No person was found to have education above secondary level. However, the respondents belonged to petty business enterprise had relatively higher literacy level.

Table 3. Literacy status of the respondents.

\begin{tabular}{|c|c|c|c|c|c|c|}
\hline \multirow[t]{2}{*}{ Literacy status } & \multicolumn{2}{|c|}{ Agriculture } & \multicolumn{2}{|c|}{ Petty business } & \multicolumn{2}{|r|}{ All } \\
\hline & No. & Percent & No. & Percent & No. & Percent \\
\hline Able to sign only & 29 & 64.44 & 17 & 37.78 & 46 & 51.11 \\
\hline Primary & 8 & 17.78 & 16 & 35.55 & 24 & 26.67 \\
\hline Secondary & 8 & 17.78 & 12 & 26.67 & 20 & 22.22 \\
\hline Above secondary & - & - & - & - & - & - \\
\hline All & 45 & 100 & 45 & 100 & 90 & 100 \\
\hline
\end{tabular}

Source: Field Survey, 2017

While analyzing the literacy level of the family members ( 6 and above), it was observed that more or less equal proportion of the family members of both the groups were illiterate. The respondent households taking together who could able to sign only primary, secondary and above secondary levels of education were to the extent of $12.69,44.03,25$ and 6.71 percent respectively during the study (Table 4). Most of the respondent households irrespective of category attempted up to primary level (44.03 percent) in the villages. 
Table 4. Educational level of the respondent household members.

\begin{tabular}{lcccccc}
\hline Literacy status & \multicolumn{2}{c}{ Agriculture } & \multicolumn{2}{c}{ Petty business } & \multicolumn{2}{c}{ All } \\
\hline & No. & Percent & No. & Percent & No. & Percent \\
\hline Illiterate & 16 & 11.43 & 15 & 11.72 & 31 & 11.57 \\
Able to sign only & 20 & 14.28 & 14 & 10.94 & 34 & 12.69 \\
Primary & 60 & 42.86 & 58 & 45.31 & 118 & 44.03 \\
Secondary & 32 & 22.86 & 35 & 27.34 & 67 & 25.00 \\
Above secondary & 12 & 8.57 & 6 & 4.69 & 18 & 6.71 \\
All & 140 & 100 & 128 & 100 & 268 & 100 \\
\hline
\end{tabular}

Source: Field Survey, 2017

\subsubsection{Occupational status of the respondents}

It is evident from Table 5 that the respondents appeared to be housewives to the extent of 60.00 and 42.22 percent for agriculture and petty business respectively. It was also observed from the same table that agricultural day laborers seems to be the main occupation of about 26.68 percent and petty business to be the secondary occupation of 53.34 percent . It was also observed that tailoring as main occupation was equally important to both groups (4.44 percent). So, it may be concluded that most of the respondents of the study area were housewives (Alam, 2005). In the case of subsidiary occupations, 75.00 and 83.90 percent of the respondents were found to serve as housewives respectively among agriculture and petty business enterprises.

Table 5. Occupational status of the respondents.

\begin{tabular}{lcccccccc}
\hline \multirow{2}{*}{ Occupation } & \multicolumn{4}{c}{ Agriculture } & \multicolumn{3}{c}{ Petty business } \\
\cline { 2 - 10 } & \multicolumn{3}{c}{ Main } & \multicolumn{2}{c}{ Subsidiary } & \multicolumn{2}{c}{ Main } & \multicolumn{2}{c}{ Subsidiary } \\
\cline { 2 - 10 } & No. & Percent & No. & Percent & No. & Percent & No. & Percent \\
\hline Housewife & 27 & 60.00 & 18 & 75 & 19 & 42.22 & 26 & 83.90 \\
Agriculture day labor & 12 & 26.68 & 3 & 12.50 & - & - & - & - \\
Petty business & 2 & 4.44 & 2 & 8.33 & 24 & 53.34 & 5 & 16.11 \\
Tailoring & 2 & 4.44 & 1 & 4.17 & 2 & 4.44 & - & - \\
Service & 2 & 4.44 & - & - & - & - & - & - \\
Total & 45 & 100 & 24 & 100 & 45 & 100 & 31 & 100 \\
\hline
\end{tabular}

Source: Field Survey, 2017

\subsubsection{Average size of land holding of the respondent households}

In the present study, land use pattern as well as ownership was investigated into eight categories as shown in Table 6. The table reveals that average size of own land was 16.4 and 21.08 decimals and that of average cultivated land was 45.68 and 8.22 decimals for agriculture and petty business groups respectively (Begum, 2006). It was evident from the table that the respondents did not have ponds either of own or leased in status (Pallavi et al., 2002).

Table 6. Average land holding of the respondents households (in decimal).

\begin{tabular}{clll}
\hline SI & Type of land & Agriculture & Petty business \\
\hline 1 & Own cultivated land & 7.02 & 6.09 \\
2 & Land rented out & - & 0.54 \\
3 & Land rented in & 37.02 & 2.13 \\
4 & Mortgaged in & 1.46 & \\
5 & Mortgaged out & 0.40 & 0.80 \\
6 & Garden & & \\
7 & Pond & 0.49 & 1.69 \\
8 & Homestead & 8.49 & 11.96 \\
9 & Total & 55.06 & 23.07 \\
10 & Average own land (legal status) $(1+2+5+6+7+8)$ & 16.40 & 21.08 \\
11 & Average cultivated land(defect to status) $(1+3+4)$ & 45.68 & 8.22 \\
\hline
\end{tabular}

Source: Field Survey, 2017 
3.1.5 Average Annual Income of the Respondent Households

Income is the most important indicator of socio-economic status of people in rural as well as in urban environments. Table 7 indicates the annual income earned from different IGAs under the SSS micro credit program. For the respondent households of agriculture enterprise, average annual income was Tk 80726.57 while the same for petty business enterprise was Tk 74864.14 .

Table 7. Average annual income of the respondent households (Tk).

\begin{tabular}{llllllll}
\hline Sources & Agriculture & $\begin{array}{l}\text { Petty } \\
\text { business }\end{array}$ & Tailorin & $\begin{array}{l}\text { Rickshaw/Van } \\
\text { pulling }\end{array}$ & Service & Other & Total \\
\hline Agriculture & 55037.70 & 5288.88 & 6000 & 4000 & 6400 & 4000 & 80726.57 \\
& $(68.18)$ & $(6.54)$ & $(7.43)$ & $(4.95)$ & $(7.93)$ & $(4.95)$ & $(100)$ \\
Petty & 11823.16 & 45733.33 & 3200 & 2888.88 & 5333.33 & 5884.44 & 74864.14 \\
business & $(15.80)$ & $(61.08)$ & $(4.27)$ & $(3.86)$ & $(7.12)$ & $(7.87)$ & $(100)$ \\
All & 33530.43 & 25511.10 & 4600 & 3444.44 & 5866.66 & 4942.47 & 77795.35 \\
& $(42.96)$ & $(32.80)$ & $(5.91)$ & $(4.43)$ & $(7.55)$ & $(6.35)$ & $(100)$ \\
\hline
\end{tabular}

Source: Field Survey, 2017

Figures in the parentheses indicate percentages of total

\subsubsection{Average annual expenditure of the respondent households}

The average expenditure of a respondent household was incurred mainly for three purposes, i.e. agricultural expenditure meeting farm expenses comprising all sorts of expenses relating to production of agricultural commodities; expenditure for non-agricultural sector included the expenses relating to business, purchase of land, land mortgaged in, purchase of agricultural implements, purchase of live animal, etc. and family expenditure, only the expenses for buying commodities from the market in exchange of cash were taken into account in the present study (Madhura, 2007). Expenditure for social ceremonies, house repairing, education, clothes, medical treatment, repayment of old debt etc. were also included in family expenditure. Table 8 showed that average annual expenditure of the respondents households. The average annual expenditure of the agriculture and petty group was Tk 78776.65 and 67912.37 respectively.

Table 8. Average annual expenditure of the respondent households (Tk).

\begin{tabular}{lllll}
\hline Enterprise & \multicolumn{2}{c}{ Expenditure } & Total \\
\cline { 2 - 4 } & Agriculture & Non-agriculture & Family & \\
\hline Agriculture & 22679.76 & 2416 & 53680.89 & $(100)$ \\
& $(28.79)$ & $(3.07)$ & $(68.14)$ & 67912.37 \\
Petty business & 4729.26 & 10188 & 52995.11 & $(100)$ \\
& $(6.96)$ & $(15.01)$ & $(78.03)$ & 73344.51 \\
All & 13704.52 & 6302 & 53338 & $(100)$ \\
\hline
\end{tabular}

Source: Field Survey, 2017

Figures in the parentheses indicate percentages of total

\subsubsection{Average annual savings of the respondent households}

Average annual savings of the respondent households were calculated by subtracting total expenses from corresponding total income during the study year. Table 9 indicated that the average annual savings of the respondent households were Tk 3733.25 and 8475.09 . It expressed that petty business households saved more money to agriculture households in the study area.

Table 9. Average annual savings of the respondent households (Tk).

\begin{tabular}{lccccc}
\hline Enterprise & $\begin{array}{c}\text { Average } \\
\text { annual income }\end{array}$ & $\begin{array}{c}\text { Average annual } \\
\text { expenditure }\end{array}$ & $\begin{array}{c}\text { Average annual } \\
\text { savings }\end{array}$ & $\begin{array}{c}\text { Compulsory savings in } \\
\text { SSS society }\end{array}$ & $\begin{array}{c}\text { Total } \\
\text { savings }\end{array}$ \\
\hline Agriculture & 80726.57 & 78776.65 & 1949.92 & 1783.33 & 3733.25 \\
Petty business & 74864.14 & 67912.37 & 6951.76 & 1523.33 & 8475.09 \\
All & 77795.35 & 73344.51 & 5745.83 & 1653.33 & 7364.16 \\
\hline Sour
\end{tabular}

Source: Field Survey, 2017

Figures in the parentheses indicate percentages of total 
3.1.8. Impact of SSS credit on poverty alleviation

This section aims at focusing the impact of SSS credit operation on the beneficiaries regarding their income, assets position, expenditure and socioeconomic status between before and after joining the SSS credit program. At present the poor households in some areas are somehow dependent on different projects of NGOs for their income generation and to improve their assets position. The NGOs have created an opportunity for the poor to survive at minimum standard level (Miah et al., 2006).

\subsubsection{Participation of women in household decision making}

The SSS program is expected to make a break through in this very aspect and so attempted to examine how far the SSS could explore the possibility of women's participation in decision making relating to family affairs. Table 10 depicts whether any change in decision making status of women has occurred because of involving into SSS credit program in the study villages. Male dominated role in household affairs has been reduced to a greater extent after the women joined the SSS activities. The activities where the male members previously took monopoly decision could realize that females should also join in decision making for smooth running of IGAs adopted by them. Taking joint decision in other family affairs also has increased considerably (Rahman, 2009). The worth mentioning result in this aspect is evident in the case of children education (60.00 percent), labor employment (40.00 percent), crop production (55.00 percent), taking care of children (30.00 percent), and rearing poultry birds.

Table 10. Participation of women in household decision making.

\begin{tabular}{|c|c|c|c|c|c|c|}
\hline \multirow[t]{2}{*}{ Heads of participation } & \multicolumn{3}{|c|}{ Before joining the SSS } & \multicolumn{3}{|c|}{ After joining the SSS } \\
\hline & Men only & $\begin{array}{l}\text { Women } \\
\text { only }\end{array}$ & $\begin{array}{l}\text { Men in } \\
\text { consultation } \\
\text { with women }\end{array}$ & Men only & Women only & $\begin{array}{l}\text { Men in } \\
\text { consultation } \\
\text { with women }\end{array}$ \\
\hline Crop production & 100 & - & - & 30 & 15 & 55 \\
\hline Labor employment & 80 & - & 20 & 60 & - & 40 \\
\hline Product marketing & 75 & - & 25 & 25 & 32 & 43 \\
\hline Rearing poultry birds & 15 & 65 & 20 & 12 & 69 & 19 \\
\hline Taking care of children & 16 & 64 & 20 & 15 & 55 & 30 \\
\hline Child education & 70 & - & 30 & 22 & 18 & 60 \\
\hline Rural meeting & 100 & - & - & 100 & - & - \\
\hline Rural activities & 100 & - & - & 90 & 10 & - \\
\hline
\end{tabular}

Source: Field Survey, 2017

\subsubsection{Changes in socio-economic indicators of the respondents}

This section describes some other impacts of participation in SSS micro credit program as perceived by the participating women. Change of socioeconomic variables towards proper use as well as repayment thereof, scaled to measures was expressed in terms positive change and no change at all (Asad, 2003). The changes of sample participants after joining the SSS are shown in Table 11. The table shows that increase awareness of the participation was satisfactory while only 13.33 percent of the respondents had unchanged awareness. After joining the SSS micro credit program, 94.45 percent of total respondents opined that there has been more or less change in education of family member. The positive change in family income (91.11 percent) was satisfactory during the study. After joining the SSS, involvement in different organization increases. Actually rate of positive changes found satisfactory in most of the indicators except involvement of women in social activities. During the study, no negative change was found. 
Table 11. Changes in socio-economic indicators of the respondents.

\begin{tabular}{llll}
\hline Items & Positive change & No change at all & Total \\
\hline Income & $82(91.11)$ & $8(8.89)$ & $90(100)$ \\
GO and NGO organizational involvement & $90(100)$ & - & $90(100)$ \\
Involvement in social and political organization & $90(100)$ & - & $90(100)$ \\
Food and nutrition & $80(88.89)$ & $10(11.11)$ & $90(100)$ \\
Housing condition & $70(77.78)$ & $20(22.22)$ & $90(100)$ \\
Health facilities & $55(61.06)$ & $35(38.89)$ & $90(100)$ \\
Clothes & $80(88.89)$ & $10(11.11)$ & $90(100)$ \\
Education & $85(94.45)$ & $5(5.55)$ & $90(100)$ \\
Awareness & $78(86.67)$ & $12(13.33)$ & $90(100)$ \\
Pure drinking water & $63(70)$ & $27(30)$ & $90(100)$ \\
Adoption of family planning & $82(91.11)$ & $8(8.89)$ & $90(100)$ \\
Using sanitary latrine & $60(66.67)$ & $30(33.33)$ & $90(100)$ \\
Savings & $75(81.33)$ & $15(18.67)$ & $90(100)$ \\
Involvement of women in social activities & $18(20)$ & $72(80)$ & $90(100)$ \\
\hline
\end{tabular}

Source: Field Survey, 2017

\subsubsection{Problems faced by the respondents to bring favorable changes}

Some questions were asked about the problems and constraints that hindered the respondents to bring expected and favorable changes by using SSS micro credit during the interview. The major problems and constraints have been presented in Table 12 .

Table 12. Problems and constraints faced by the respondents.

\begin{tabular}{lllll}
\hline Problems and constraints & High & Moderate & Not at all & Total \\
\hline Lack of sufficient credit supply & $20(22.22)$ & $40(44.45)$ & $30(33.33)$ & $90(100)$ \\
High interest rate & $33(36.67)$ & $30(33.33)$ & $27(30.00)$ & $90(100)$ \\
Burden of old debt & $10(1.67)$ & $35(48.49)$ & $45(50.00)$ & $90(100)$ \\
Lack of suitable marketing facilities & $40(44.44)$ & $50(55.55)$ & - & $90(100)$ \\
Low price of different products & $35(38.88)$ & $55(61.11)$ & - & $90(100)$ \\
Lack of storage facilities & $33(36.67)$ & $32(35.55)$ & $25(27.72)$ & $90(100)$ \\
Lack of improved seeds/breed & $35(38.88)$ & $40(44.42)$ & $15(16.37)$ & $90(100)$ \\
Theft & & $40(44.45)$ & $50(55.55)$ & $90(100)$ \\
\hline
\end{tabular}

Source: Field Survey, 2017

From above table it is found that there are eight kinds of major problems which were opined by the respondents in the study area during the time of study. Here, the respondents expressed their problems in three degrees like 'high' 'moderate' and 'not at all' a problem. The answers given by the respondents against different problems were carefully handled and presented in percentage to be meaningful (Uddin, 2002). The highest (66.67 percent) proportion of the respondents reported insufficiency of credit supply was a moderate problem and only 33.33 percent of them reported this not at all a problem to them. The interest rate charged by the SSS as a major problem, 36.67 percent of the respondents opined is as high. The respondents of the study area repaid their old debt which sometimes creates problems to utilize their credit for selected occupation. About 48.49 percent of the respondents reported that burden of old debt was not at all a problem while 1.67 percent said that it was a great problem to continue their existing activities. On the other hand, 36.67 percent of the beneficiaries reported lack of storage facilities as a great problem. Lack of improved seeds/breeds sometimes stands as problem to the women beneficiaries.

\subsection{Recommendations for policy implications}

a) The amount of fund should be raised, so that the farmers can easily get loan as much as amount they needed;

b) Credit should be provided at low interest rate;

c) SSS should facilitate training on IGAs to the members so that they would be able to use loan properly and in position to repay their loan on time;

d) Loan installment can be started after 2-3 months after loan receipt instead of 15 days;

e) SSS should provide marketing facilities to the beneficiaries so as to have fair price for their products;

f) The respondents also suggested that SSS should provide technical knowledge to the beneficiaries, which would help them to earn more profits from investment. More profit from investment will surely encourage in 
repayment of loan timely.

\section{Conclusions}

The credit holders of SSS improved their livelihood as well as social status after involvement in SSS. Women participation in decision making of family affairs has been recognized by their male counterparts after joining the SSS group. The SSS micro credit program could have positively changed some of the socio-economic indicators of the beneficiaries. SSS microcredit has made a positive contribution to reduce poverty from the study area. The study suggests for further study of similar type in other areas within the domain of SSS findings which would encourage the policy makers to formulate pragmatic program for rural development in the country in future.

\section{Conflict of interest}

None to declare.

\section{References}

Alam ABMN, 2005. Rural women in micro-credit programs of poverty alleviation: a study of BRAC in sadar upazila of Netrokona district. M.S. Thesis, Department of Agricultural Finance, Bangladesh Agricultural University, Mymensingh.

Asad M, 2003. A socio-economic study on livestock and fisheries program for women beneficiaries of BRAC in Mymensingh district. M.S. thesis, Department of Agricultural Finance, Bangladesh Agricultural University, Mymensingh.

Badiuzzaman M, 2006. An analysis of grocery loan under rural development scheme (RDS) of Islami Bank Bangladesh Limited (IBBL) in sadar upazila of Mymensingh district. An unpublished Master's Thesis, Department of Agricultural Finance, Bangladesh Agricultural University, Mymensingh.

BBS, 2016. Statistical Year Book of Bangladesh, Ministry of Planning, Government of People's Republic of Bangladesh, Dhaka.

Begum K, 2006. A study on the ASA handicraft credit in sadar upazila of Jamalpur district. An Unpublished Master's Thesis, Department of Agricultural Finance, Bangladesh Agricultural University, Mymensingh.

Bulbul T, 2010. A comparative economic analysis on microcredit programs of vegetables cultivation and beef fattening of Jagorani Chakra Foundation (JCF) in some selected areas of Jessore district. M.S. Thesis, Submitted to the Department of Agricultural Finance, Bangladesh Agricultural University, Mymensingh.

Islam S, 1999. Micro-credit for the poor, a study of small farmers development project (SFDP) in sadar upazila of Bogra district. M.S. Thesis, Submitted to the Department of Agricultural Finance, Bangladesh Agricultural University, Mymensingh

Jalil MA, 2005. Impact of micro-credit program of RDRS on rural women in some selected areas of Kurigram district. M. S. Thesis, Submitted to the Department of Agricultural Finance, Bangladesh Agricultural University, Mymensingh.

Kabir MS, 2004. A study on small entrepreneurship development and socio-economic upliftment of rural women in some selected areas of Mymensingh District. Master's Thesis, Department of Rural sociology, Bangladesh Agricultural University, Mymensingh

Khatun MN, 2009. A study on the present agricultural credit structure in selected areas of Kushtia district. M.S. Thesis, Submitted to the Department of Agricultural Finance, Bangladesh Agricultural University, Mymensingh.

Madhura S, 2007. The microcredit alternative? Economic and Political Weekly, 42: 1171-1175.

Pallavi C and R Ramakumar, 2002. Micro-credit and rural poverty: an analysis of empirical evidence. Economic and Political Weekly, 37: 955-965.

Miah MAK, Alam AKMA and Rahman AHMA, 2006. Impact of agricultural credit on MV boro rice cultivation in Bangladesh. Journal of Agriculture and Rural Development, 4: 161-168.

MoF, 2016. Bangladesh Economic Review, Economic Division, Ministry of Finance, Government of the People's Republic of Bangladesh, Dhaka, Bangladesh.

Mustaree S, 2010. Effects of micro-credit provided by organization for rural advancement (ORA) on the beneficiaries in some selected areas of Kishorganj district, M.S. Thesis, Submitted to the Department of Agricultural Finance, Bangladesh Agricultural University, Mymensingh.

Rahman, 2009. The impact of RDRS micro credit program on rural livelihood and women empowerment in some selected areas of Rangpur district. M.S. Thesis, Department of Agricultural Economics, Bangladesh Agricultural University, Mymensingh. 
SSS, 2016. Annual Report, 2015-16, Mymensingh, Society for Social Service.

Uddin MH, 2002. A study on the impact of grameen bank credit program on rural women beneficiaries in a selected area of Mymensingh district. Department of Agricultural Finance, Bangladesh Agricultural University, Mymensingh.

UNDP, 2016. State Of World Population, 2016, New York [online]. Available from: http://www.unfpa.org/swop. Accessed 2nd December, 2016. 